LUKE 7:36-50: SEE THIS WOMAN?

\title{
TOWARD A THEOLOGY OF GENDER EQUALITY IN THE CONTEXT OF HIV AND AIDS
}

\author{
Miranda N Pillay \\ Department of Religion and Theology \\ University of the Western Cape
}

\begin{abstract}
The Aids pandemic presents challenges that are varied and complex, and thus it requires exploring unique and creative responses by all sectors of society, including the church. Skewed gender power-relations, and particularly the marginalization of women are understood (among the many exacerbating factors) to be contributing to the spread of the HI-virus. The perceived inferior nature of women has made them socially, economically and sexually more vulnerable to contracting the HI-virus. Women unfriendly readings of the Bible have contributed to attitudes and practices in church and society which affirmed patriarchy and the subjugation of women as "the natural order of things". " This article explores how a woman deemed "invisible" by the natural order of things, transcends oppressive attitudes and practices by claiming freedom and equality in public assembly. This re-reading of Luke 7:36-50 is an invitation to re-discover the transformative potential of a New Testament text in the light of past (and present) discrimination and the androcentric reading of Biblical texts that contribute to, and sustain the marginalization of women $^{2}$ in the church and society.
\end{abstract}

Key concepts: Luke 7: 36-50, gender equality, HIV/Aids

\section{Introduction}

The scientific, social, economic, legal, ethical, spiritual and theological challenges of HIV and Aids on individuals, families, faith communities and society, and the possible future threat that it holds for all of humanity, are dramatic challenges which need a collaborative, coordinated response from all levels of society. A major dimension of the response to HIV/Aids is the transformation of power relationships which oppress, discriminate against, and dominate women. The church has a significant contribution to make in this regard. This contribution lies primarily in its embodiment as a worshiping community where people come to see the world and each other differently and hence here it can envisage a world of complimentarity and equality in relationships. However, there is a major problem in that the primary resource for such a new vision - the Bible - is itself characterised by patriarchy and has been interpreted to reinforce male domination. Hence what is suggested in this

Read: beliefs and practices that support and sustain the status quo of hierarchical power structures.

Schüssler-Fiorenza (1993:15) warns against Western universalist views that all women are defined in the same way in their otherness to men. South Africa women will certainly agree that their experiences as women are influenced by issues of race, culture, economics, religion, politics, etc. 
article, is that an alternative reading of scripture can contribute to a new theology, which in turn can be embodied in worship.

Christian churches continue to be an important factor in South African society. ${ }^{3}$ While the HIV/Aids pandemic challenges Christian churches (and other faith communities) to respond to the needs of those persons infected and affected, it is also an (urgent) opportunity for Christians to reflect anew on how they see themselves in relation to God and to others.

There has been an awakening to the realities of the Aids pandemic among certain churches, of which many have projects and programmes in place. ${ }^{4}$ However, Aids presents challenges to Christian theology that are "uncomfortable". It sometimes calls for thinking and speaking theologically about the sexed-body - about taboos such as sex and sexuality, gender based violence etc. But more so, Christian theology is challenged to re-examine the views, beliefs and practices that render people vulnerable to the HI-virus. The present reality of poverty, sexism, gender power-relations, death, exclusion, stigma and scapeoating intensifies the complexity of the challenges presented by the Aids pandemic. Keeping in mind the multiple and complex nature of these challenges, the focus of this article is on a theology of gender equality. The plausibility of Scripture as a basis for gender equality is explored with Luke 7:36-50 being foregrounded as an example of the possible liberative potential of New Testament texts. This first has to be placed within the context of a brief overview and evaluation of the church's response to HIV and Aids.

\section{The Church's Response to HIV/Aids}

What church is and stands for differs from person to person. In two informative articles about the uniqueness of the church, Dirkie Smit (1996a:119-129; 1996b:190-204), describes six "manifestations" of the church as:

a) The worshipping community - during church on Sunday (worship service);

b) The local church - the congregation / parish;

c) A denomination - the institutional church (DRC, CPSA, etc) $;^{5}$

d) The ecumenical church - representing different denominations (WPCC, SACC, WCC); ${ }^{6}$

e) Volunteer organizations, civil initiatives, e.g. CBCOs and FBOs; ${ }^{7}$

f) Individual members - living their (everyday) lives according to the values of Christianity.

Many churches in various communities are responding to the HIV/Aids pandemic from one or more of these six operational concepts of "church", of which many are doing a lot of "caring" work. Some have "awareness" campaigns and workshops to address the issues of stigma that surround HIV/Aids and the impact it has on the lives of those affected and infected. Public pronouncements about what the church ought to be doing also reflect some

\footnotetext{
Eighty percent of South Africans claim to be Christian, according to the population census of 1996 www.gov.za/yearbook/rainbow.htm

$4 \quad$ Nicolson (1995:7) explains that the churches' slow response to HIV/Aids is understandable if one considers that other problems in South Africa, especially the injustice, the violence and the political volatility, seemed more immediately urgent. There are other reasons for the churches' slow response - and continued reluctance from some churches - including the (previously held) view that Aids is a homosexual disease or that Aids is God's judgment on the sexual impurities of homosexuals and promiscuous people, who "deserve" it. .

Dutch Reformed Church; Church of the Province of Southern Africa.

6 Western Cape Council of Churches, South African Council of Churches and World Council of Churches. Church Based Community Organizations and Faith Based Organizations.
} 
churches' response to the challenges around HIV and Aids. Some church leaders' profiles afford them an international platform from where the church's voice is heard.

At grassroots level, the churches' response of care, compassion, embrace and service is vital in terms of reacting appropriately to the pandemic and is indeed part of what the church ought to do. Physical, emotional and spiritual care for persons infected together with awareness campaigns and workshops have contributed toward "breaking the silence" around the disease.

But to speak of HIV and Aids and not also of sex and sexuality, and the relationships of power within which they occur, would be "obscene." ${ }^{\text {" }}$ HIV/Aids has been described as an "equal opportunity" disease, but those who are economically and socially marginalized are more vulnerable. ${ }^{10}$ Women in Sub-Saharan Africa are now worst affected by the HIV/Aids pandemic. According to Saayman (1992:51), this may be linked to the strong patriarchal character of traditional African society in which young unmarried women have little defence against sexual advances from older, more powerful men. This view is reiterated by Madipoane Masenya (2003:122) who observes that women whose sexuality "is not under the legitimate control of a particular man become easy prey to satisfy male lust". However, Masenya argues that the issue of unilateral control of women's bodies is not uniquely African. The "women-unfriendly" interpretations of the Bible often cement the inferior position of the wife in marriage (Schüssler-Fiorenza 1995:270). Traditional gender roles and power relations in churches have contributed to social constructs within which the marginalization of women continues to flourish. African woman theologian Mercy Amba Oduyoye (1995:182) writes:

Whatever is keeping subordination of women alive in the church cannot be the spirit of God. The church is intended to be the ecclesia of all people, women and men across all social barriers. In the church we expect to experience the reciprocity, mutual respect, support and protection of each person's freedom in continuum with our freedom as the children of promise.

An integral part of addressing the HIV/Aids pandemic is to challenge the kyriocentric language and adrocentric interpretation ${ }^{11}$ of biblical texts that legitimize and perpetuate the subordination of women (and other marginalised groups). Women, and particularly South African women who are still suffering the discriminatory effects of apartheid and who are continuously struggling against gender power-relations, are experiencing a triple jeopardy in their vulnerability to HIV/Aids. ${ }^{12}$ Musimbi Kanyoro (2001:161) rightfully observes that justice for women is often trivialized in favour of "larger issues such as national liberation, famine, disease, war and poverty". These "larger issues" are intensified by the impact of HIV/Aids and vice versa. While the church is responding to HIV and Aids from what has been described earlier as the institutional church, ecumenical church, local congregation and as volunteer organisation ( $\mathrm{CBO}$ and $\mathrm{FBO}$ ), the challenge is for the church to respond as

There is, however, still a deafening silence from some church groups who believe the disease is "out there" while others adopt a judgmental approach believing that HIV/Aids is God's punishment for sinful behaviour.

Here I take my cue from Weeks (1995:15) who states it the other way round, "To speak of sexuality and the body, and not also of Aids, would be obscene."

10 Women, more so than men, are also physiologically vulnerable to being infected.

11 By kyriocentric language, I mean discourses which sustain the domination and subjugation of master/servant relationships. Androcentric interpretation refers to the 'creation of meaning' from a male perspective.

12 That of racism, classism and sexism. Ageism also is another dimension to consider, as it is elderly women, with limited resources, who now have to take care of grandchildren as economically active parents become ill and die of Aids-related diseases. 
Worshipping Community. Herein lies the key to making Christian theology relevant to the realities of problems that challenge worshippers in their everyday lives.

\section{The Church as Worshipping Community}

Worship is the locus of theology. Local congregations are communities of people who come together to worship in fellowship. During worship, Christians remember God's great act of love and because of this remembrance of God's salvific love, there is hope. While Christian worship provides creative opportunities for affirming how "we see" God, ourselves, others and the environment, in which and with which we interact, it also provides unique opportunities to help us "look in the right direction". ${ }^{13}$ It is within the "space" created during worship that the opportunity exists for the changing of the hearts and minds of Christians. As Elna Mouton (2003:16) puts it:

The worship service, as the central point of all ecclesial activities and experiences, is essentially rhetorical in nature. It is the primary context where believers are continuously constituted and affirmed as a community of believers, as the 'household of God'. It is the primary location where a collective identity is assigned to them, where they learn to know who they are and "Whose" they are. This is where they learn to dream about God's future which has already become a reality in Christ, and from where they are being sent out to care for one another and the world. From here God's household (as a social, communicative, domestic, economic entity) moves into society to proclaim God's presence in the liturgy of everyday life.

A study document of the World Council of Churches (1997:78) describes worship as "a special moment for celebration - an attempt to place daily life on the stage". It further states that:

Worship can help churches to remove the barriers we create in the everyday life of our human communities by opening our eyes, our ears and all our senses to the extraordinary significance of the 'ordinary' experiences and to ways of expressing God's presence amidst the people and creation (1997:78-79).

Christian worship has ethical implications for public life because worshippers learn to see the world in a certain way, says Smit (1997:261). In the worship service the Spirit moulds and refines our senses - we learn to listen anew to God's word, to each other and to the needs of society. We learn to look and see in new ways. In reference to the Reformed tendency to link worship with transformation, justice and ethics, Smit (1997:270) observes that the worship service leads to a second form of service - "The believers accept mutual responsibility for each other in their spiritual and physical needs".

It is during worship that the space could be created for opportunities "to look in the right direction" in order to re-shape the worshipping community's thoughts, beliefs, attitudes and actions with regard to gender power-relations. Thus, Christian clergy are challenged to reflect on "the will to look and see differently". The use of gender inclusive language during worship is a case in point.

For the church to respond to the theological challenges presented by the Aids pandemic, it has to respond from the basis of its unique nature which, as mentioned before, encompasses "six manifestations". In this regard, I make two observations. The first is that, the present response of the church misses unique opportunities - to be the church as

13 Smit (1997:272) warns, though, that Christian worship is an ambivalent phenomenon - while it has the potential to change the way we see things, it can (and has been) used to avoid what we should see and thus it can entrench the status quo. 
"worshiping community". Presently, the church's (very important) response of care for the infected, awareness workshops, seminars and special "Aids church services", are addenda ${ }^{14}$ to the church. ${ }^{15}$ I want to suggest that by responding from its unique nature, which includes the church as worshiping community, the church could ensure that its response to HIV and Aids does not remain broad public statements, that its response is not buried in official church documents, and that its response does not only include the rendering of services that are no different to that of the many NGOs who are also responding to the Aids pandemic.

The second observation is that many clergy persons do not regard addressing issues around HIV and Aids as part of their pastoral duties, but instead opt to invite people from Aids organizations to address their congregations. Does this not question the theological basis for responding to HIV and Aids? ${ }^{16}$ How does one speak (and preach) about human sexuality, life, death, power, stigma, community, care, respect, love etc. in the context of HIV and Aids? How can Christian individuals and communities be moved from fear and despair to hope and joyful living? How can Scripture, as a focal point in liturgy, be used to transform hearts and minds?

\section{The Bible: A Basis for (Gender) Equality?}

It goes without saying that, as a woman of colour in post-apartheid South Africa, I will have to account for the usefulness of the Bible in addressing gender oppression in the $21^{\text {st }}$ century. It is widely acknowledged and documented that the Bible had been used to legitimize slavery, racism, sexism and other discriminatory and exploitative perceptions and practices. In the process many people, and Christian women in particular, have become deeply suspicious of the often repressive readings of the Bible which are imposed on them (albeit unwittingly), and which cause them to feel like second class citizens in the Kingdom of God. Very often women (and other marginalized groups) feel disillusioned and deceived by the many "successful" ways in which Scripture is used to justify and solidify gender apartheid and other forms of exclusion. South African New Testament scholar, Elna Mouton (2003:5-6) explains:

Through a lack of credibility on the side of preachers and theological institutions, mainly because of repressive ways in which the Bible has been used in the past, many people seem to have lost their trust and confidence in the liberating power of the Word of God. For such people to be surprised (again) by Scripture's transformative and liberative power, and to be persuaded by virtues such as truthfulness, authenticity and integrity (while lacking appropriate role-models), have indeed become an enormous theological challenge to Christian theology.

Scripture, however, continues to function in Christian discourse as a source of insight and hope, and thus has the potential to influence the ethos of Christian communities in South Africa. This, says Smit (1991:57), is because once texts "penetrate deeply into the psyche, especially the collective psyche, they cease to be primarily objects of study and rather come to supply the conceptual and imaginative vocabularies, as well as the grammar and syntax with which we construe and construct reality". The Bible, according to Smit (1991:59),

14 This is also my experience as a member of a local congregation/parish and a regular participant in worship, within the CPSA.

15 The way the Aids message has been presented in "tedious campaigns that have served to alienate rather than inspire, and the dullness of the message underpinned by a false and naïve morality" has also resulted in boredom with the issue (Crewe 2000:11).

16 In response to my views in this regard, a clergy person remarked, "Aids is a scientific problem with social ramifications, do you intend giving it a theological twist?" 
influences the imagination and language of society. It influences the way people "see" things; it influences their vision, their grasp of reality and history. Thus the Bible influences the moral world because it shapes the way people see their world and how they speak about their world. The "world" of apartheid in South Africa was primarily shaped, influenced and sustained by the interpretation of biblical texts. But the same Bible was also used by those who opposed apartheid and its oppressive practices. Women-unfriendly biblical interpretations which sustained the subjugation of women therefore are to be challenged, and modes of interpretation that affirm the equality of women must be explored. Instead of androcentric interpretation that illuminate (albeit unintentionally) the supposed "sinful, inferior nature of women", the challenge should be to address and transform oppressive interpretations, traditions and doctrines.

The above argument shows that the multi-dimensional nature of biblical texts often results in multiple and ambiguous interpretations. This is why Mouton (1994:21) aptly reminds us that the Bible does not supply direct, simple answers to moral questions raised in contemporary society. While the present challenges of the Aids pandemic are not directly addressed in New Testament texts written centuries ago; views, rituals and practices (about God and others) that alienate, discriminate, stigmatize and subjugate are challenged by the Jesus movement. I thus concur with Mouton (1995:188) who asserts that, "[...] we (Christians) have the obligation (and responsibility) to involve ourselves in the creative tension of the liminal space between the dynamics of the Biblical texts and the needs of contemporary society".

Scripture is the primary source from which Jesus' vision of "freedom for all" can be gauged. But how do we read and interpret these ancient documents? This is a complex question where histories of tradition(s) and methodological paradigms have to be considered. Up until the last four decades, biblical interpretation, dominated by white male scholars, evolved around the historical-critical method. Today, influenced by feminism and liberation theology, many women and men challenge this "scientific" method of biblical interpretation. ${ }^{17}$ Feminist biblical scholar, Elizabeth Schüssler Fiorenza observes that despite her endeavour over the past twenty odd years to contribute feminist theoretical insights to biblical studies, it is clearly noticeable that feminist critical models for literaryhistorical and political-rhetorical inquiry have yet to be taken seriously. The exclusion of feminist and liberationist scholarship from mainstream (malestream?) biblical scholarship is because interpreters "remain in the captivity to empiricist-positivist science", says Schüssler Fiorenza. Influenced by feminist hermeneutics the efforts of African women theologians challenge the traditional male, individualistic, hierarchical, and often competitive approach to biblical interpretation. The interpretive efforts of African women theologians have the distinctive characteristic of inclusiveness. This inclusivity emphasizes solidarity among sister theologians, while it also acknowledges that both men and women must re-read and discover the liberative potential of biblical texts for all people. As Teresa Okure (1993:77) observes, an African women's approach to biblical interpretation "describes the efforts of women and men to interpret the scriptures as they relate to women, in a common search for new inclusive meanings". This is an important angle from which to explore scriptures because for many people in Africa and South Africa, gender inequality is

17 Pioneered by white North American and European women, feminist hermeneutics became identified with white women theologians' approach to reading Scriptures. In response, black American women theologians argue that their experiences as women differ from that of their white sisters, and thus refer to their approach as "womanist". 
sustained by hierarchies of economic, political and religious exploitation and this inequality is exacerbated by poverty and disease which affect women, and men.

The realities of HIV and Aids are experienced by many people, whether infected or affected. Thus, to respond theologically to the challenges of HIV and Aids means to respond to the realities of how people view themselves and others, in the light of these challenges. This means that a theological response cannot be "owned" solely by the institutional church, but also by the people. This I have argued, calls for a response from the church as "worshipping community", because this is where people are "moved" to see differently; this is where most Christians hear Scripture being read and interpreted. The premise of this article is that the Aids pandemic is exacerbated by gender inequality and that this inequality, particularly the subjugation of women is sustained by kyriocentric views and androcentric interpretation Scripture. Thus the plausibility of Scripture as a basis for challenging discriminatory views and practices was explored. In my view feminist hermeneutics within the framework of African women's theology offers a reliable tool for negotiating interactive dialogue among women and men. This will contribute toward ensuring that the spiral of hermeneutics continues to revolve to include disenfranchised voices and marginalized voices. Robbins ${ }^{18}$ (1999:58-60) reiterates the importance of a continuous revolving hermeneutic spiral which includes "disenfranchised voices, marginalized voices, recently liberated voices, and powerfully-located voices" in addition to the voices of women and marginalized people (1999:58). I now turn to the gospel of Luke and then to the foregrounded text (Luke 7:36-50). This reading, "guided" by a feminist hermeneutical framework, is done against the background of Vernon Robbins's article, "Using a Socio-Rhetorical Poetics to Develop a Unified Method: The Woman who anointed Jesus as a Test Case" (1992:302-314). While my interpretation will reflect North American scholarly insights, it also reflects my position as a woman theologian of colour, who shares space and experience with many African women and men, for whom Western scholarly methods of interpretations often make no(n)sense.

\section{Women in Luke's Gospel}

The New Testament documents, and particularly the gospels, were written during times of uncertainty (Bosch 1993:8-10) to encourage people to see, speak and act in ways that would move them from despair to hope. Luke, in particular, understands Jesus' earthly ministry as "one in which people on the fringes of society receive compassion and as a ministry to which the church of his time is called" (Bosch 1993:10). Many biblical scholars have observed that Luke has a special place for women in his gospel and that he reflects the ministry of Jesus as being concerned with the liberation of people from the grip of powers which hold them prisoner. For me, Luke particularly challenges the way men "see women" and the way women "see themselves".

Right at the beginning Luke tells of Elizabeth, who was shamed into silence by a society that sanctioned motherhood as the primary source of honour for her. Luke gives her a public voice through the "shame" of Zechariah's disbelief. Luke "moves" Elizabeth into the public space by silencing the priest and father of their child - whom she gets to name (Lk 1:59). The husband's voice returns only after he acknowledges publicly that he is in agreement with his wife's decision.

18 Vernon K Robbins, professor in New Testament Studies at Emory University, is a leading biblical scholar engaged in Socio-Rhetorical Interpretation, an interpretive programme which he claims lends itself to integrating the positive contributions from various competing methodologies. 
Unlike Matthew, for whom the male figure (of consent) in Joseph takes centre stage during the visit of "an angel of the Lord" (Matt 1:20), Luke has the angel visit Mary - not only as a (unwed) woman who has to deal with pregnancy and birth, but also as a woman who consents to the event ( $\operatorname{~k~1:38).~The~young~pregnant~Mary~ignores~the~social~}$ conventions of her time and travels alone to visit her cousin, Elizabeth, "in the hill country of Judea" (Lk 1:39).

Then there's Mary Magdalene and Joanna, Susanna and many other women who followed Jesus (Lk 8:2-3). In Luke 10:38-42 we read about Martha and her sister Mary, who joined the other disciples in learning from Jesus - in a culture that did not permit women to study with men. Luke also mentions women whom he does not name: the widow of Nain (Lk 7:11-17); the woman who anoints Jesus' feet (Lk 7:36-50); a woman's bleeding stopped after twelve years of suffering physically, emotionally and economically (Lk8:44) after she, who is considered to be "unclean" dared to touch Jesus (Lk 8:47); the daughter of Jairus is raised in a culture that valued boy children more (Lk 8:54); the crippled woman whom Jesus healed on a Sabbath, much to the dismay of the synagogue ruler (Lk 13:10-14); the humble contribution of the poor widow which is valued highly (Lk 21:1-4); the parable of a woman who invites neighbours to celebrate her finding the lost coin (Lk 15:8-10); the persistent widow who moves the unjust judge to action (Lk 18:1-5). Luke acknowledges the presence of women among those who mourn for Jesus on His way to the cross (Lk 23:27). Luke chooses women to bear witness to Jesus' dead body (Lk 23:55) and also to witness the empty tomb (Lk 24:1-3). The women who told the "Eleven and all the others" are named (Lk 24:9-10). Luke shows how the apostles (eleven men?) doubt the women (Lk 24:11). However, Peter sensed the urgency and importance of their message and ran to the tomb (Lk 24:12).

Luke presents women as a group of people who, in exceptional ways, combine social insecurity and exclusion with autonomous energy and resources. He depicts a movement from social marginalization and impurity to social integration and purity. Luke also presents Jesus as one who makes women visible to others by publicly affirming their credibility and dignity. Luke presents Jesus as being a conduit of change in the lives of women (and men) by challenging boundaries which had been created by notions of women's sinfulness (Lk 7:36-50).

\section{See this Woman? Luke 7:36-50}

If one is in agreement with those who argue for the priority of Mark, it could be said that Matthew gives a similar account, and takes his cue from Mark in placing the story of "the woman who anoints Jesus" towards the end of Jesus' ministry and within the context of his death. By contrast, the Lukan story unfolds in the context of Jesus' healing ministry. While Luke describes the woman as one who "had lived a sinful life", ${ }^{19}$ both Matthew and Mark describes her as being wasteful (Mk 14:4; Matt 26:8). ${ }^{20}$ It is not clear according to Mark what Jesus was doing in the home of Simon the Leper. Luke states that Jesus was a dinner guest at the house of "one of the Pharisees" (7:36). Perhaps he was one of the Pharisees who had rejected Jesus earlier ( $\mathrm{Lk} 7: 30)$ ? It appears that the possible affluence and religious status of Simon (the Pharisee) in the Lukan account, versus the possible need of Simon (the Leper) in the Markan account, influenced the way the men (and others) present perceived

9 New International Version.

20 John (12:1-8) describes a dinner at the home of Lazurus, with Martha serving food, while Mary is identified as the woman who anoints Jesus feet with expensive perfume and Judas objects to her being extravagant. 
the woman's actions. I do not agree with Tannehill (as cited in Robbins 1992:307) that the woman was "seeking something". I would argue that the woman was coming to acknowledge what she had already found. According to Luke (7:37) "she brought an alabaster jar of perfume". This means that she had gone to the Pharisee's house with a purpose, "to do and not to seek". Could it be that she had already found what she had been seeking? Was she perhaps among those who have experienced Jesus' healing power as described by Luke from the beginning of that chapter ( $\mathrm{Lk} 7: 1 \mathrm{ff})$ ? Is it possible that she shed tears of joy for sins already forgiven, instead of tears of sorrow for the sinful life? If this is possible, I would concur with Tolbert (Robbins 1992:307) that, "the anonymity of the woman and her act of love proclaim her affinity with the faithful ones healed in the earlier days". This woman boldly entered a home where she clearly was not welcome. Did she risk entering the Pharisee's house believing that she will not be condemned and judged by Jesus and those who kept company with him (Lk 6:37)?

Robbins (1992:318) advises that the boundaries of intertextual interpretation should be widened to include "the Mediterranean world in which early Christians lived, to widen the social and cultural boundaries to include customs, behaviours, and attitudes of people in Mediterranean society". He also reiterates the importance of widening ideological boundaries "beyond a culture of the mind to include a culture of the body." Whatever the woman's reason for crying, her tears wet Jesus' feet. This is quite possible as Jesus reclined at the table according to the Graeco-Roman practice, his feet would have been sticking out. Tannehill (1996:135) states that there is no evidence that foot washing was an integral part of hospitality, whereas Witherington (1995:65-66) argues that foot washing was part of the system of hospitality of first century Christianity. While I am not sure of any "proof" of this practice in first century Mediterranean society, it appears that Jesus was accustomed to it and expected his host to comply (Lk 7:44). ${ }^{21}$ According to Robbins (1992:313) there appears to be no comparative texts to give evidence to whether anointing a guest's feet with oil and kissing them were customary or whether such a public exhibition of affection would be embarrassing to the one receiving such affection or those observing it. Nevertheless, the Pharisee regarded her action to be improper. It was, however, Jesus' acceptance of this "woman of the city who was a sinner" that raised (confirmed?) doubt in the Pharisee's mind about Jesus' honourability as a prophet (Lk 7:39). But by knowing and challenging the Pharisee's thoughts, Jesus' credibility goes unchallenged as the Pharisee acknowledges Jesus as "teacher" (7:40). ${ }^{22}$ The parable that follows provides a different angle / criterion from which to judge the situation. Simon is asked to make a judgment between two debtors whose response to the merciful creditor was influenced by the amount they owed.

Jesus then turns toward the woman and draws Simon's attention saying, "Do you see this woman?" The analogy between Simon's doubt (which resulted in him withholding care) and the woman's bold faith (which moved her to acts of care and affection) is a strategy intended to have Simon see the woman, see himself and see God (as one who pardons debt) in a new light. Luke's hearers are moved toward a new configuration of attitude toward this woman. The woman becomes visible and her dignity, as one who responds appropriately, is restored. This characteristic of the rhetorical process says

21 In John's account, hospitality towards Jesus as guest of honour in the home of Lazarus, Martha and Mary, included "feet washing".

22 In a chapter entitled Honor and Shame in Luke-Acts: Pivotal Values of the Mediterranean World, Bruce Melina and Jerome Neyrey deal with dimensions at work in "honour-shame" dynamics. Jesus, knowing what the Pharisee thinks, thus maintains his own honor and "he achieved new honour by his success in shaming his challengers" (1991:50). 
Robbins (2001:1) "emerges at the moment that sound from the mouth moves another person toward action; or toward a new configuration of feeling, attitude, belief, or understanding". A discourse that offered an alternative way of "seeing" (understanding) and "being" (acting) was characteristic of Christians living, distinguishing them from their pagan and Jewish neighbours in the broader Graeco-Roman context (Robbins 2001:3). Because of the struggles between the emerging transformative view of the Christian movement and that of the dominant patriarchal ethos of the Greco-Roman world, the leadership roles assumed by women were often ignored, submerged and pushed aside.

I concur with Robbins (1992:313) who suggests that we should consider it important to deal seriously with the culture of the body and that our theologies should not be limited to "a culture of the mind". He reasons that such a culture (of the mind) could be "governed by a kind of male ideology that is not able to work sympathetically, sensitively and physically with other people's bodies without imposing sexual intentions, manipulations and violations".

\section{From a Theology of Dominion and Separateness ...}

The gospels portray Jesus as being free of the pernicious gender polarization of human history. However, the prominence of women did not go unchallenged. Every variety of ancient Christianity that advocated the equality of women was eventually declared heretical. Gradually evidence of women's leadership roles was erased and suppressed. Schüssler Fiorenza (1990:20) argues that, although only remnants of a non-patriarchal Christian ethos are preserved in the Bible, "[T] these remnants indicate that such a 'patriarchalization' process was not inherent in [the early] Christian community, but progressed slowly". Elsewhere, Schüssler Fiorenza (1983:84) also observes that the gradual patriarchalization of the early church was unavoidable, because as the Christian movement became institutionalized, women were excluded from church office or their positions were reduced to subordinate marginal ones.

The oppression of women ${ }^{23}$ is the most universal form of exploitation which supports and perpetuates other forms of oppression in society and the church. Men's dominion over women is derived from representing the image of God as man. "Man" who is seen as presenting the rational and spiritual part of the self, while woman is seen as having a "greater aptness for sin". Theologians such as Augustine, Thomas Aquinas, Luther, and philosophers such as Kant, Nietzsche and Freud have advocated a negative theology or philosophy of "woman" (Schüssler-Fiorenza 1993:13). ${ }^{24}$ The origins of sexism in the Christian tradition are related to the dualistic worldview, which identifies God with the positive (that which is perfect) and "the world" with the negative (that which is imperfect). Theologies or theories of the "abstract universal woman as body, sexuality, maternity or nature" have sustained gender imbalanced discourses that understand "man" as the subject of history, culture, and religion (Schüssler-Fiorenza 1993:13).

23 I concur with Schüssler-Fiorenza (1993:20) that women "do not have a unitary essence but represent a historical multiplicity, not only as a group but also as individuals".

24 Nietzsche-like misogyny advocates, "... only he who is sufficiently man will redeem the woman in woman; for the woman the world is perfect only when she obeys with all her love." Nietzsche thus contends that man is creator, he is redeemer, and he is commander, while woman is the chaos that cries for the imposition of order. This view reiterates the notion that woman is sinful and awaits redemption; that she is irrationality that must receive command. Volf (1996:190) observes that such a construction of gender goes in one direction from the positive of man's fullness towards the negativity of woman's lack. 
With regards to canonical texts, Landman (2001:83-87) observes that fourth century "church fathers" deliberately excluded texts which reveal leadership roles of women to combat what they perceived to be heretical teaching. I agree with Landman's appeal to extra-canonical texts such as The Gospel of Mary and The Acts of Thecla, which explicitly reveal women's involvement in teaching, preaching and officiating in the early Christian movement,. However, I do not agree with her assertion that women in the Bible can only be used today as "negative sources to demonstrate the lack of human dignity and visibility" or with her claim that women in the Bible "are an embarrassment to their modern sisters" (Landman 2001:83). I would argue that, although the details of some of the gospel stories may be questionable, they reflect the prominent historical roles of women within the sociocultural situatedness of first century Christianity. And instead of accepting views, traditions, practices interpreted through androcentric filters, serious questions must be raised in order to discern what it means to be "children in the household of God" (Eph.3:19) As Christians who today share the history of God's salvific love with those who first followed Jesus, it is our duty to read and re-read Scripture.

\section{Toward a Theology of Radical Equality and Relationality}

Womanhood added a significant dimension to the marginalization of women of the Bible. ${ }^{25}$ This phenomenon has not changed much since. In some instances today, women are ostracized by the men in their communities for "giving them Aids". And so, again, it is women who have to bear the "sin" of sexual immorality, a notion sustained by theologies and theories that view women as "sinful" and seductive. Yeoman (1997:34) argues that theology is a science and because theologies are human constructs, they reflect the origins and biases and interests of those who formulate them. Like all sciences, theology must change and develop with changing knowledge and experience. The realities of HIV and Aids remind us that, despite the simplest impulse to withdraw from each other, we are bound to each other. In literature on Aids, largely prompted by stigmatization that results in fear, despair and alienation, there has been a resurgence of themes such as love and care. In our response to HIV and Aids we have to develop an ethic of love which includes alternative narratives of care, respect, responsibility and trust.

Elsewhere I have written about responding responsibly to the Aids pandemic, which entails responding in both re-active and pro-active ways (Pillay 2003:118). In this article I suggest that, by addressing gender power-relations, the church could strengthen its proactive response to HIV/Aids. For the Christian church, it is primarily a theological question, rooted in the rhetoric of moving from theology of hierarchy, of male headship, of power and dominion based on separateness, to a theology of community, mutuality and relationality.

Socially constructed gender inequalities continue to shape our views, attitudes and actions which make genuine caring relationships a perilous task. It often enforces dependencies that make love a duty, a punishment, or a trap (Weeks 1995:177). The fact that women are often perceived as the ones doing "caring work" associated with domesticity, keeps them trapped in the oblivion of the private sphere and sustains the elevated position of men in the visible public sphere. Men and woman should share mutual responsibility in the physical caring of the sick. The urgency of HIV and Aids demands that men also commit themselves to the domesticity of care-giving. This is the first dimension in what I see as a theology of communal care. A second dimension is that a truly loving

25 In addition to being marginalized economically, socially, politically and religiously. 
care can only be built on the equality of caregiver and the person being cared for (Weeks 1995:179). I see our equal vulnerability to the HI-virus as the basis of this equality. The urgency of HIV and Aids demands that we step out of the notion that "Aids is out there", that it is the disease of homosexuals, of drug addicts and of the sexually promiscuous. Our humanity is dependant on our caring and responsible involvement in the lives of others.

Both these dimensions of a theology of communal care are exhibited in the story of the woman who cares for Jesus in a physical way. Jesus points out that he expected such care from Simon. Did Simon perhaps think Jesus is not deserving of such care, since the Pharisees were questioning his teaching? The woman's act of service did not render her inferior, but resulted in Jesus acknowledging her publicly. Jesus acknowledged the woman's dignity of which the basis is respect.

Respect, says Weeks (1995:182), takes serious the dignity of the other, "both their autonomy as persons, and their needs for you and for others". Dignity is lost when subjectivity and reliance on the other is thwarted by false polarities and hierarchical relations. Respect for the dignity of "the other" is impossible in the context of the Aids pandemic if we do not care enough to stop the spread of the virus. This implies the need to challenge the views, attitudes and practices which render women economically and sexually vulnerable. The challenge, says Weeks (1995:183), is "a working through of the transformations of personal relationships that have already fundamentally undermined the basis of (hierarchical) gender relations." The essence of such transformation includes a shift from oppressive relationships based on dominion to life-enhancing relationships based on mutuality and reciprocity.

Croatian systematic theologian Miroslav Volf refers to the "mutual and reciprocal relationality" of the persons in the Trinity (1996:175-181). He presents the Trinity as a nonhierarchical relationship between separate persons. In doing this, Volf affirms the notion of mutual giving of the self, while not losing the self, as the pivotal point to be considered in gender power-relations. He uses the passion of Christ to explain the internal dialogue within the Trinity, which for him becomes the ultimate model for mutuality, reciprocity and equality.

Mutuality, says Russel (1974:165), means that one shares consciousness and trust, not that one becomes identical to that person. Mutual interpellation, continues Russel, is a style of "thinking your way together into action". This means that diverse groups are willing to risk change by joining together in dialogue around a common problem. But in order for men and women to sincerely "join together" around the common problem of HIV and Aids, attention must be given to skewed gender power relations sustained by patriarchy, and nurtured by the church.

\section{Concluding Remarks}

The disastrous socio-economic effects of HIV and Aids have sharpened the focus on gender inequality in general and the vulnerability of women in particular. While the church has responded socially, the realities of HIV and Aids further challenge the church to respond theologically. ${ }^{26}$ It is a tragedy that the church does not always respond theologically to societal needs. One major concern in this regard is the interpretation of the Bible. Women unfriendly readings of Scripture contribute to views of women as weak, subservient, seductive and sinful. Responsible re-reading/s of Scripture with the view of retrieving its

26 Here I hasten to add that the social obligation and response by the church is not void of theological reflection. 
liberative and transformative potential is therefore a challenge to the present-day church. Feminist hermeneutics and the approach of African women theologians offer ways of reading Scripture that would reflect positively on women by challenging androcentric readings. A theological response to HIV and Aids necessitates appealing to Scripture.

The rapid spread of the HI-virus and the impact on the lives and livelihoods of many are challenging all people to reflect on how we see ourselves in relation to others, and to God. I have suggested that it is when church members gather as a worshipping community that the opportunity presents itself to change the way we "see". This is where the reading and interpretation of Scripture form the basis of liturgy. It is during worship that our attitudes of prejudice, indifference, intolerance and carelessness may be challenged. And this is also where we are reminded of our Christian sense of community; of our responsibility to and for others; of our relationality which calls for respect, mutuality and reciprocity.

The Aids pandemic provides reflectors through which we can witness the uncertainties of attitudes to life, love and death - but also the possibilities which are giving them new meanings. There is an urgent need to relate to others in ways that are "life-affirming". ${ }^{27} \mathrm{We}$ can only do so if we are honest and acknowledge our common humanity and our common vulnerability as human beings - whether black, white or brown; male or female; homosexual or heterosexual; HIV-positive or HIV-negative; rich or poor.

\section{BIBLIOGRAPHY}

Bosch, David 1993. Good News for the Poor ... and the Rich. Pretoria: CB Powell Bible Centre (UNISA).

Combrink, HJB 1999. The Challenge of making and redrawing boundaries: A Perspective on Socio-Rhetorical Criticism. Nederduitse Gereformeerde Teologiese Tydskrif 40, 1830 .

Crewe, Mary 2002. A University Response to HIV/Aids, Aids Analysis Africa 10 no. 5 (Feb/Mar 2000), 11-12.

Kanyoro, Musimbi 2001. Engendered Communal Theology: African Women's Contribution to Theology in the $21^{\text {st }}$ Century. In Nyambura J Njoroge and Musa W Dube (eds.), Talitha Cum:Theologies of African Women, 158-180. Cluster Publications: Pietermaritzburg.

Landman, C 2001. The Implementation of Hermeneutics. In Nyambura J Njoroge and Musa W Dube (eds.), Talitha Cum: Theologies of African Women, 83-94. Cluster Publications: Pietermaritzburg.

Malina, Bruce and Neyrey, Jerome 1991. Honor and shame in Luke-Acts: Pivotal Values of the Mediterranean World. In Neyrey, Jerome H (ed), The Social World of Luke Acts: Models for Interpretation. Hendrickson Publishers: Massachusetts.

Masenya, Madipoane 2003. Trapped between Two "Canons": African Women in the HIV/Aids Era. In Phiri, I and Haddad, B (eds.), African Women, HIV/Aids and Faith Communities, 113-127. Pietermaritsburg: Cluster Publications.

Mouton, AEJ 1994. Reading Ephesians: criteria toward a Renewed Identity Awareness? Neotestamentica 28(2), 359-375.

27 In many instances "the other" is the woman in a sexual relationship. As in many instances talking about sex is taboo for the woman in a relationship. Many women who are aware of the partners' infidelity dare not negotiate "safe sex". 
Mouton, AEJ 1995. Reading a New Testament Document Ethically: Toward an accountable use of Scripture in Christian Ethics, through analysing the transformative potential of the Ephisians Epistle. Doctoral Thesis. University of the Western Cape.

Mouton, Elna 2003. From woundedness towards healing: A rhetoric of pastoraltheological vision? $14^{\text {th }}$ National Conference: Southern African Association for Pastoral Work, Cape Town, 12-14 May 2003.

Nicolson, R 1995. Aids: A Christian Response. Pietermaritzburg: Cluster Publications.

Oduyoye, Mercy Amba 1995. Daughters of Anowa: African Women and Patriarchy. New York: Orbis Books.

Okure, Teresa 1993. Feminist Interpretations in Africa, in Schüssler Fiorenza (ed.), Searching the Scriptures: A Feminist Introduction, 76-85.

Pillay, Miranda N 2003. Church Discourse on HIV/Aids: A Responsible Response to a Disaster? Scriptura (82), 108-121.

Punt, Jeremy 1998. My Kingdom for a Method: Methodological preoccupation in areas of South African New Testament Scholarship. Neotestamentica 32(1), 135-159.

Robbins, Vernon K 1992. Using a Socio-Rhetorical Poetics to develop a Unified Method: The Woman who anointed Jesus as a Test Case. Journal of Biblical Literature (31), 303-319.

Robbins, Vernon K 1996. The Tapestry of Early Christian Discourse: Rhetoric, Society and Ideology. London: Routledge.

Robbins, Vernon K 1996. Exploring the Texture of Text: A Guide to Socio-Rhetorical Interpretation. Valley Forge, PA: Trinity Press International.

Robbins, Vernon K 2002. The Rhetorical Full-Turn in Biblical Interpretation: Reconfiguring Rhetorical-Political Analysis. In Porter and Olbricht (eds.), Rhetorical Criticism and the Bible: Essays from 1998 Florence Conference, 48-60. Sheffield: Sheffield Academic Press.

Russell, Letty M 1974. Human Liberation in a Feminist Perspective - A Theology. Philadelphia: Westminister Press.

Saayman, W 1991. Some reflections on Aids, ethics and the community in Southern and central Africa. Theologia Evangelica 24(3), 23-29.

Schüssler Fiorenza, Elizabeth 1993. Discipleship of Equals: A Critical Feminist Ekklesialogy of Liberation. New York: Crossroad.

Schüssler Fiorenza, Elizabeth 1995. Transforming the Legacy of The Woman's Bible. In Schüssler Fiorenza (ed.), Searching the Scriptures: A Feminist Introduction. New York: SCM Press Ltd.

Schüssler Fiorenza, Elizabeth 1996. Challenging the Rhetorical Half-Turn: Feminist and Rhetorical Biblical Criticism. In Porter and Olbricht (eds), Rhetorical, Scripture and Theology: Essays from 1994 Pretoria Conference, 28-53. Sheffield: Sheffield Academic Press.

Smit, DJ 1991. The Bible and Ethos in a New South Africa. Scriptura (37), 51-67.

Smit, DJ 1996a. Oor die kerk as 'n unieke samelewingsverband. Tydskrif vir Geesteswetenskappe (36)2, 119-129.

Smit, DJ 1996b. Oor die unieke openbare rol van die kerk. Tydskrif vir Geesteswetenskappe (36)3, 190-204. 
Smit, DJ 1997. Liturgy and Life? On importance of Worship for Christian Ethics. Scriptura (63), 259-280.

Snidle, H 1997. HIV/Aids: An Introduction. In Snidle, H \& Yeoman, D (eds.), Christ in Aids, 17-26. Cardiff: Cardiff Academic Press.

Tannehill, RC 1998. Luke. Nashville: Abingdon Press.

Volf, Miroslav 1996. Exclusion and Embrace: A Theological Exploration of Identity, Otherness and Reconciliation. Nashville: Abington Press.

Witherington, B 1995. Women and the Genesis of Christianity. Cambridge University Press.

Weeks, J 1995. Invented Moralities: Sexual Values in an Age of Uncertainty. New York: Columbia University Press.

World Council of Churches. Facing Aids: The Challenge. The Churches' Response. A WCC Study Document 1997. Geneva: WCC Publications.

Yeoman, D 1997. Can There be a Theology After Aids? In Snidle, H \& Yeoman, D (eds.), Christ in Aids, 27 - 35. Cardiff: Cardiff Academic Press.

www.gov.za/yearbook/rainbow.htm 